\title{
Effect of Aqueous Extract of Launaea acanthodes on Testicular Tissue and Sperm Parameters in Alloxan-Induced Diabetic Rats
}

\author{
Rahbarian R. ${ }^{1}$ PhD, Sepehri Moghadam H. ${ }^{2}$ PhD, Sadoughi S.D.* MSc \\ *Young Researchers and Elite Club, Mashhad Branch, Islamic Azad University, Mashhad, Iran \\ ${ }_{1}^{1}$ Biology Department, Sciences Faculty, Payam-e-Noor University, Tehran, Iran \\ ${ }^{2}$ Agriculture Department, Sciences Faculty, Payam-e-Noor University, Tehran, Iran
}

\begin{abstract}
Aims: Diabetes cause oxidative stress in sperm and testicular tissue. The Launaea acanthodes has anti-oxidant and anti-diabetic effects. The present study was done to evaluate the effect of Launaea acanthodes extract on sperm parameters and testicular tissue in diabetic rats.

Materials \& Methods: 27 rats were divided into the 3 equal groups; control, diabetic control and experimental diabetic. Experimental diabetic and diabetic control groups were got diabetic by an intraperitoneal injection of alloxan. Extract of Launaea acanthodes with concentration of $300 \mathrm{mg} / \mathrm{kg}$ was injected intraperitoneally to the experimental diabetic group every other day for a month. Sterile distilled water was injected to control and diabetic control groups. After creating experimental diabetes, all injections were done every other day for a month. On day 30, all rats were sacrificed and their testes were removed for assessment of sperm parameters and histological evaluation. Data were analyzed by SPSS 20 software using Kruskal Wallis and Dunn post hoc test.

Findings: Percentage of progressive motility, natural forms and the number of sperms in treated diabetic group with extract of Launaea acanthodes with concentration of $300 \mathrm{mg} / \mathrm{kg}$ were increased significantly compared to the diabetic control group $(\mathrm{p}<0.05)$. Average weight, length, width and average diameter of the tubules of the testes and the average thickness of the epithelium of the seminiferous tubule in diabetic group treated with extract of Launaea acanthodes were increased significantly compared to the diabetic control group $(\mathrm{p}<0.05)$.

Conclusion: Extract of Launaea acanthodes improves sperm parameters, increase sperm count and decrease atrophy of seminiferous tubules of diabetic rats.
\end{abstract}

\section{Keywords}

Diabetes Mellitus [http://www.ncbi.nlm.nih.gov/mesh/68003920];

Spermatozoa [http://www.ncbi.nlm.nih.gov/mesh/68013094];

Testis [http://www.ncbi.nlm.nih.gov/mesh/68013737];

Rats [http://www.ncbi.nlm.nih.gov/mesh/68051381]

\footnotetext{
* Corresponding Author

Tel: +985135013950

Fax: +985135013950

Address: Biology Department, Sciences Faculty, Payam-e-Noor University, Mo'allem Boulevard, Mashhad, Iran. Post Box: 91735-433

damoon.Sadughi@gmail.com

Received: November 22, 2014 
مقدمه

بيمارى ديابت، با سطوح بالاى قند خون و اختلال در متابوليزم

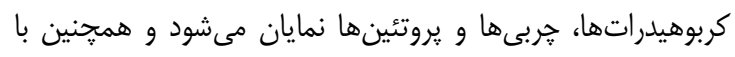

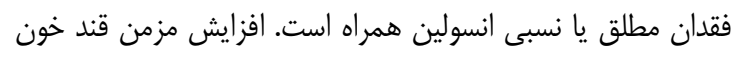

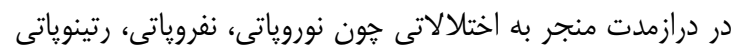

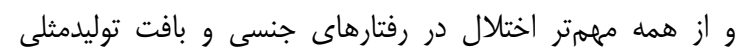

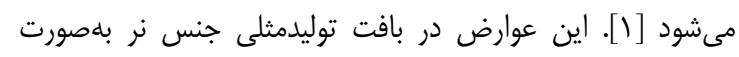

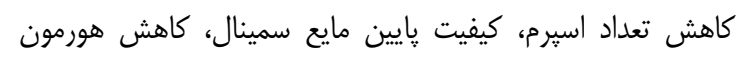

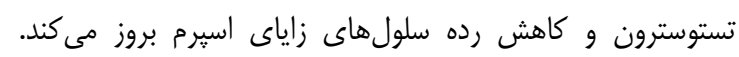
علاوه بر اين، شرايط غيرفيزيولوزيك نظير ايسكمى، افزايش دما،

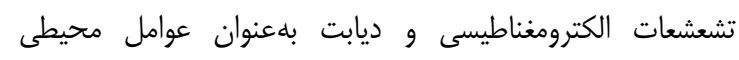
القاكننده مرگ سلولى موجب فعالشدن آيويتوز در رده سلولهن بهات

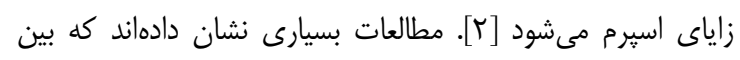
شرايط استرس اكسيداتيو در مايع منى و نقص عملكرد اسيرماتوزواً

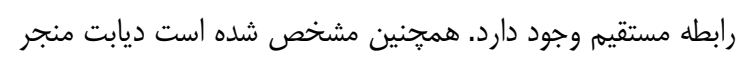

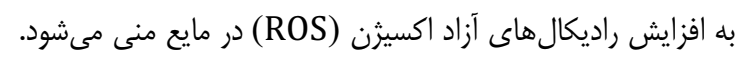

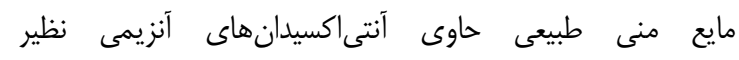

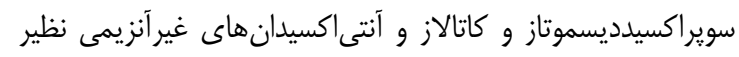

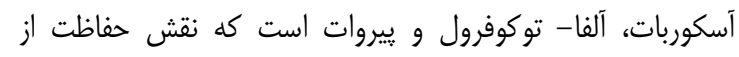

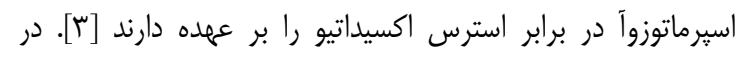

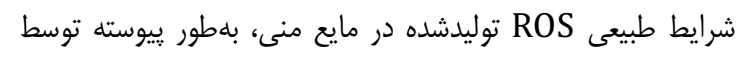

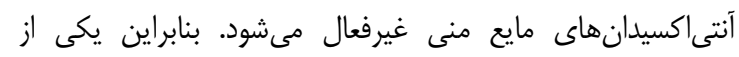

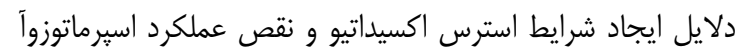

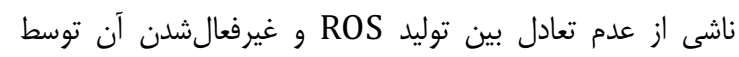

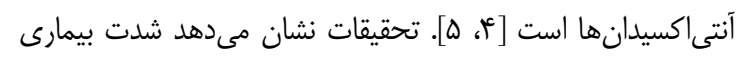

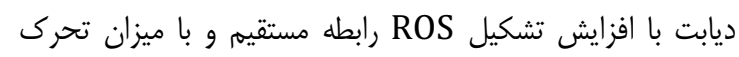
اسرקم رابطه معكوس دارد. بدين صورت كه هر خه خه ديابت شديدتر

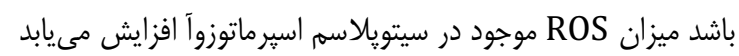

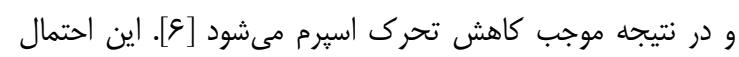

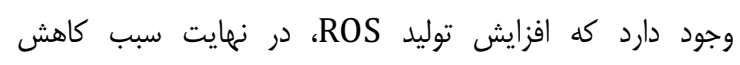

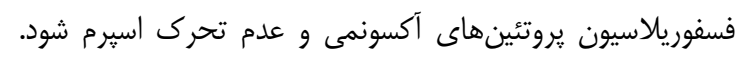

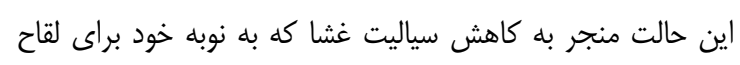

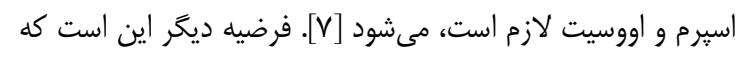

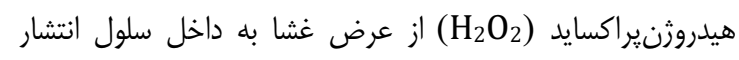

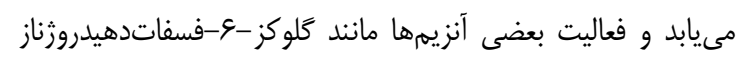

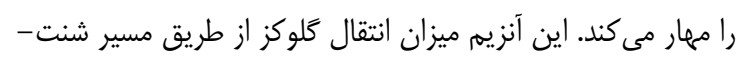

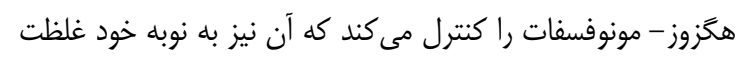

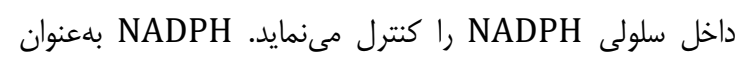

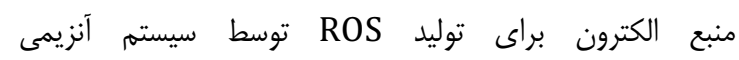

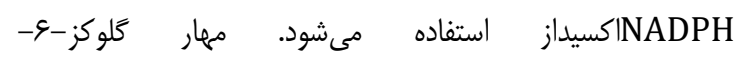
فسفاتدهيدروزناز منجر به كاهش NADPH و تجمع كلوتاتيون

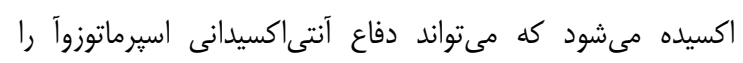

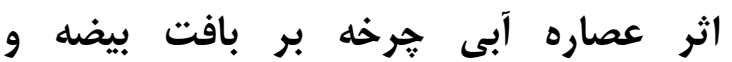

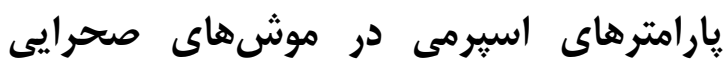 ديابتىشده با آلوكسان}

\author{
PhD راهله رهباريان \\ كروه زيستشناسى، دانشكده علوم، دانشخاه يِيام نور، تهران، ايران \\ حشمت سيهرى مقدم PhD \\ كروه كشاورزى، دانشكده علوم، دانشعاه يِيام نور، تهران، ايران \\ MSc سيددامون صدوقى
}

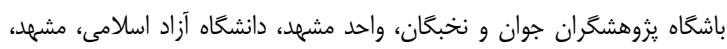

ايران

جكيده

اهداف: ديابت منجر به استرس اكسيداتيو در اسبرم و بافت بيضه

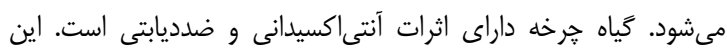

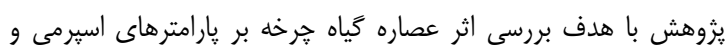
تغييرات بافتى بيضه در موشهاى صحر ايى ديابتى انجام شد. مواد و روشها:

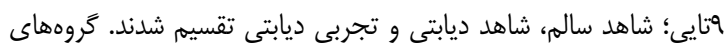

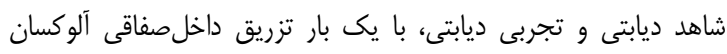

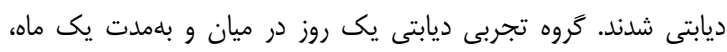

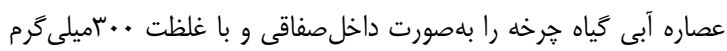

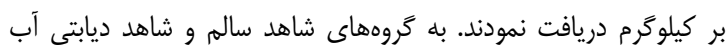

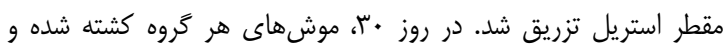

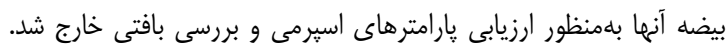

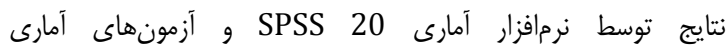
كروسكال واليس و تعقيبى دان تحليل شدند. نتان

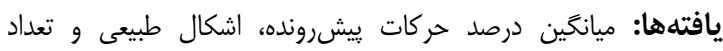

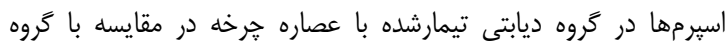

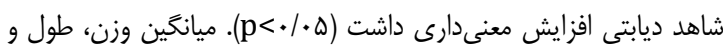

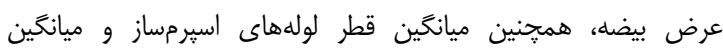

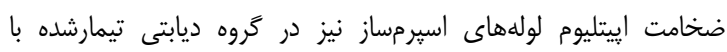

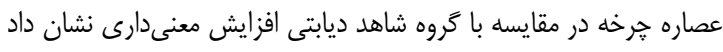

.$(\mathrm{p}<\cdot / \cdot \Delta)$

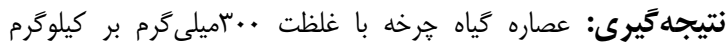

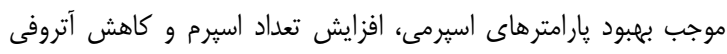
لولههاى اسيرمساز در موشهاى صحر ايى ديابتى مى بعود.

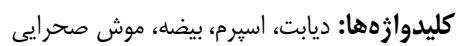

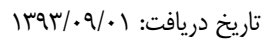

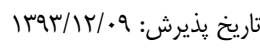

damoon.Sadughi@gmail.com : تويسنده مسئول:

دوره آr، شماره ا، بهار FaF

فصلنامه افق دانش 


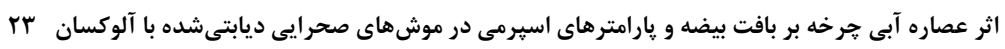

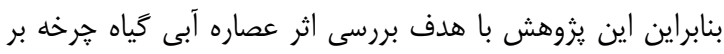

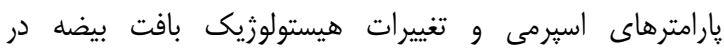

موشهاى صحر ايى ديابتى انجام شد.

\section{مواد و روشها}

در اين مطالعه تجربى كه در آزمايشگاه تحقيقات جانورى كروها

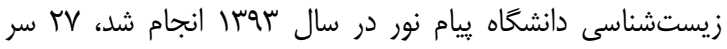

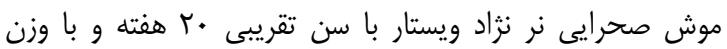

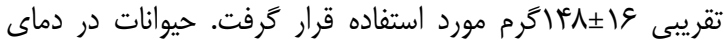
تقريبى

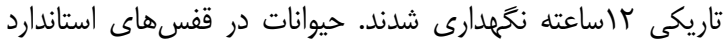
قرار داشتند و آب بهمقدار كافى توسط بطرى شيشهای داع در اختيار آنها

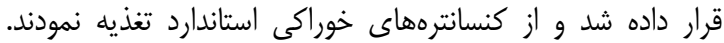

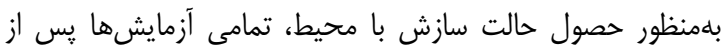

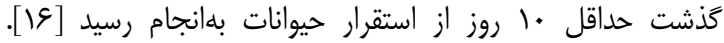
رعايت تمامى حقوق حيوانات آزمايشكاهى در بزوهش بران براي استران استفاده

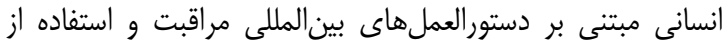

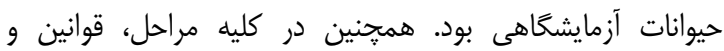
مقررات اخلاقى كار با حيوانات آزمايشگاهى رعايت شدات

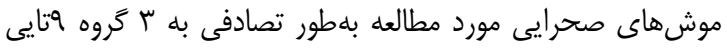

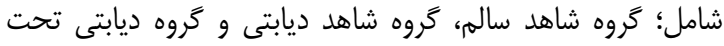

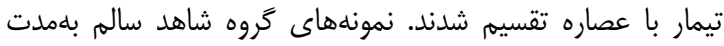

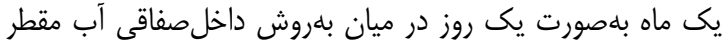

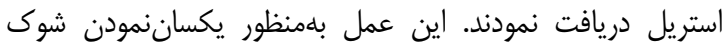

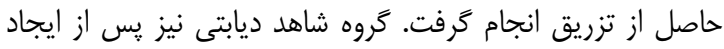

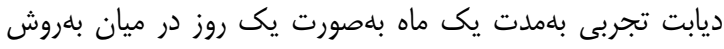

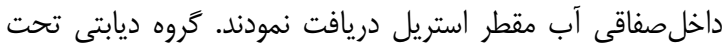

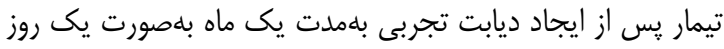

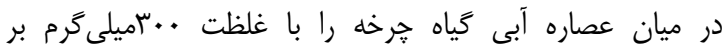
كيلوكرم بلصورت داخل صفاقى دريافت نمودند.

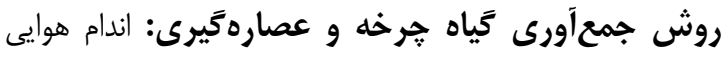

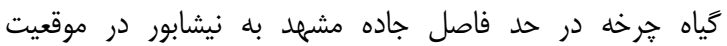

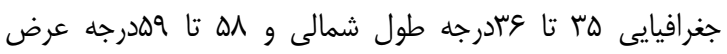

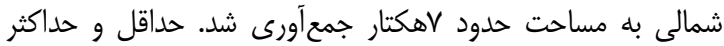

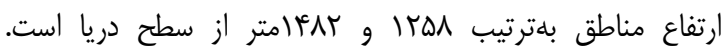
نمونههاى گياهى پِّ از جمعآورى، توسط كارشناسان محترم

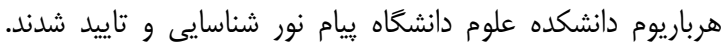

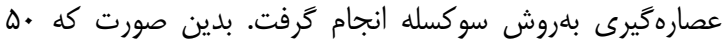

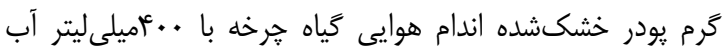
مقطر توسط هيتر برقى بلمدت • •اساعت جوشانده شد. سيس باء

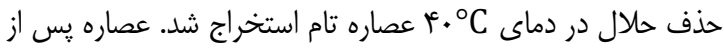

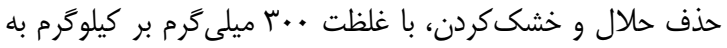

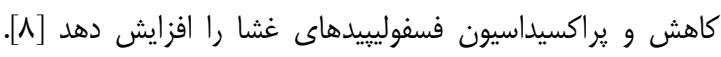

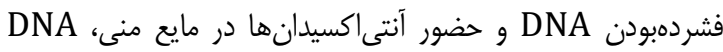

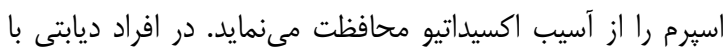

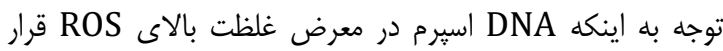
دارد موجب قطعلقطعهشدن آن مىشود. همجنين يكى دئ ديكر از

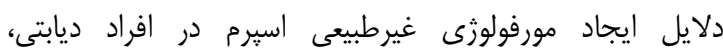

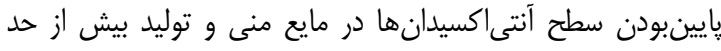
ROS در سيتويلاسم اسبرم است [9]. تحقيقات نشان داد ديابت موجب كاهش سطح هورمون تستوسترون، ناهنجارى ساختارى

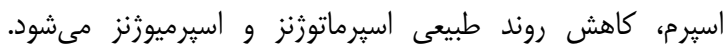
همجنين مشخص شد ديابت مىتواند موجب القاى مسير سيكنالينگ آيويتوز در سلولهاى اسيرمى و كاهش تعداد آنها شود

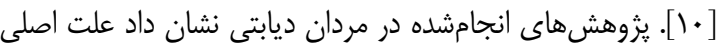

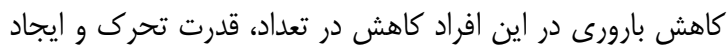

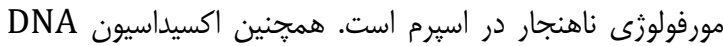

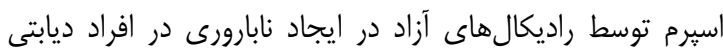

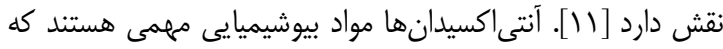
را در برابر آسيبهاى ناشى از راديكالهاى آزاد محافظت

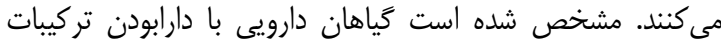

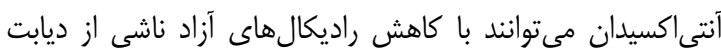

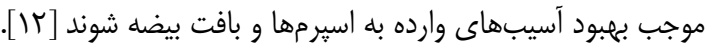
از خرخه (Launaea acanthodes (Boiss.) O. Kuntze)

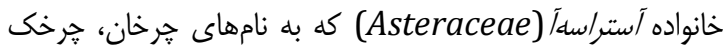

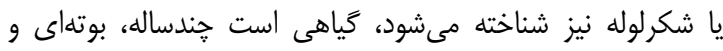

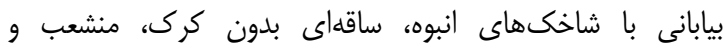

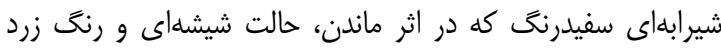

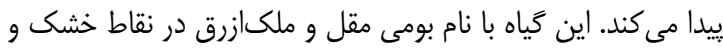

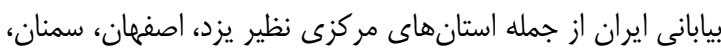

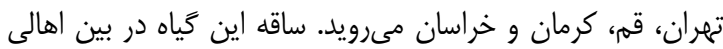
مناطق كويرى بلعنوان يك داروى كياهى موثر در درمان بران بسيارى

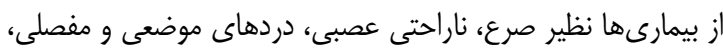

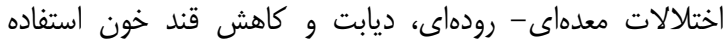

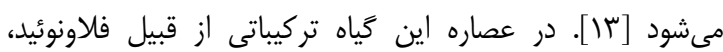

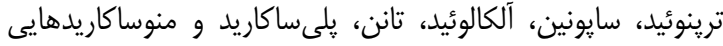

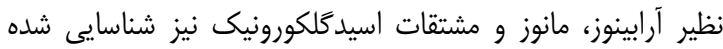

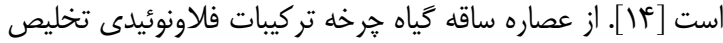
شده است. با توجه به اينكه فلاونوئيدها بهعنوان آنتى اكسيدان قاديان آنادر به كاهش سطح راديكال هاى آزاد سلولى هستند مىتوان از آنهان آنها در كاهش اثرات مخرب ديابت استفاده نمود [1ه] نشان داد كه تاكنون مطالعالى روى اثر تزريق داخلصفات داتى عصاره

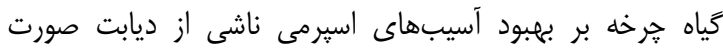

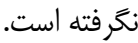


براى بررسى مورفولوزى، ابتدا يك قطره از سوسيانسيون اسِرم

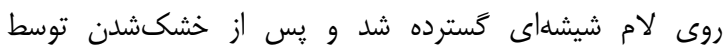

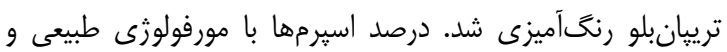

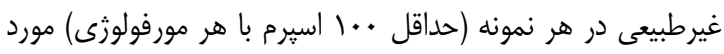

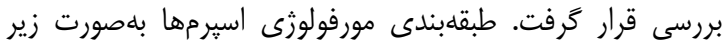

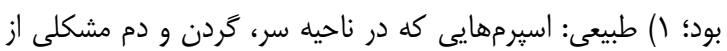
نظر ظاهرى نداشتند. r) اشكال غيرطبيعى سر: اسيرمهاى داراى نو

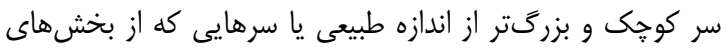

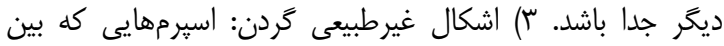
ناحيه سر و گردن زاويهاى ايجاد شده باشد يا اسيرمهايى كه دير در

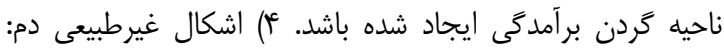

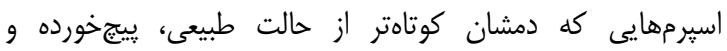
غيرطبيعى باشد. بررسى هيستولوزيك بافت بيضه: در روز ب آزمايش، بيضهها يس از خارجشدن و اندازهگيرى وزن و و ابعاد، براى

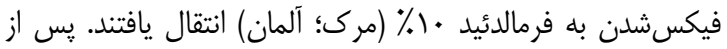

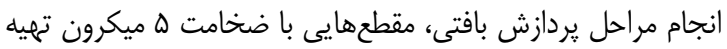

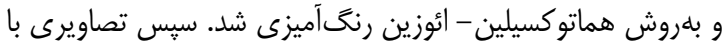

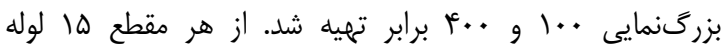
منى ساز با قطر تقريباً گرد بلهورت تصادفى انتى انتخاب شد و ميانگين

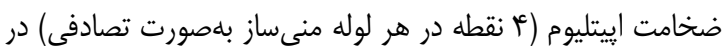

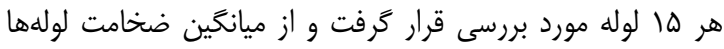

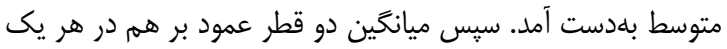
از ها لوله منىساز محاسبه شد و از ميانخين قطر لولهها متوسط

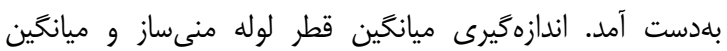
ضخامت اييتليوم در هر بيضه جهار بار تكرار و از دادهها متوسط ميط

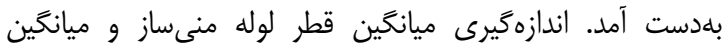
Image J ضخامت إيتليوم در تصاوير تهيهشده توسط نرمافزار 2

بررسى شد [11]. تحليل اطلاعات بهدستآمده توسط نرمافزار آمارى SPSS 20 و

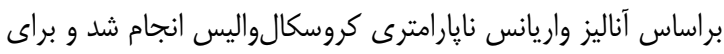
مقايسه دو به دوى گروهها، آزمون تعقيبى دان مورد استفاده قرار

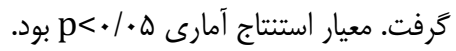

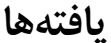

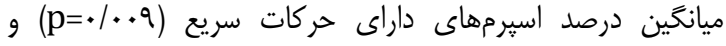

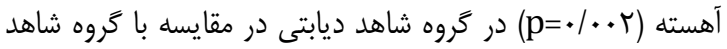
سالم بلطور معنىدارى كاهش و ميانخين درصد اسيرمهاى بدون

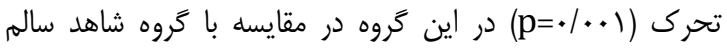
بهلور معنىدارى افزايش يافت. ميانخين درصد اسِرمهاى داراى حركات سريع و آهسته در گروه تجربى تيمارشده با عصاره گياه
حيوان تزريق شد. قبل از تزريق، محلول تهيهشده از از فيلتر

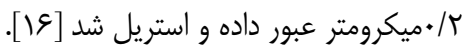

روش ايجاد هيبر كليسمى تجربى: مدل تجربى ديابت (ديابت

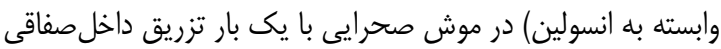

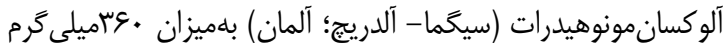
بر كيلوكرم ايجاد شد. همجنين از آب مقطر استريل بهعنوان حلال

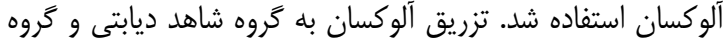

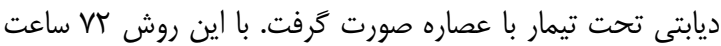

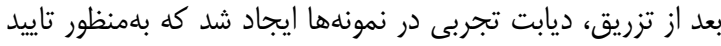

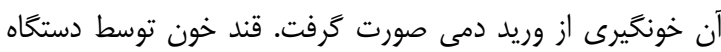

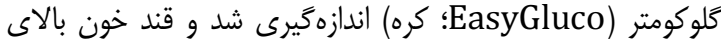

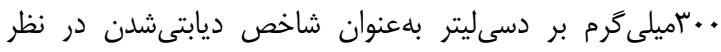

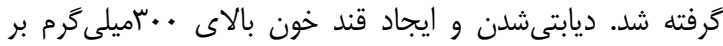

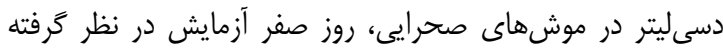

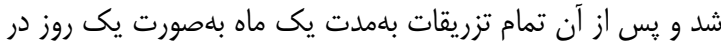
ميان صورت كَرفت [19].

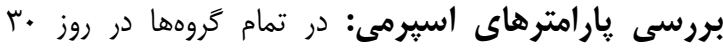
آزمايش، موشهاى صحرايى توسط استنشاق دى داتيلاتر (مرك؛

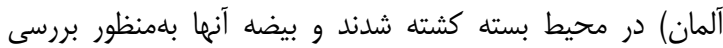

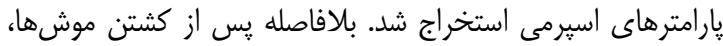
ايبديديم از بيضه جدا شده و با قيجىى استريل به قطعات كوخى تقسيم شد و با كميلى ليتر محلول نرمال سالين شستشو داده شداء

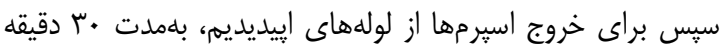

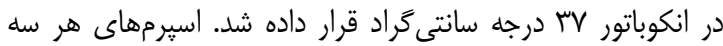

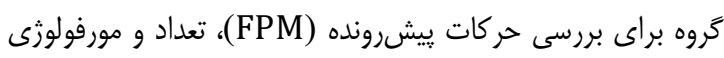

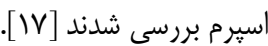
حركات ييشرونده اسيرمها بلهصورت حركات ييشروندانده سريع،

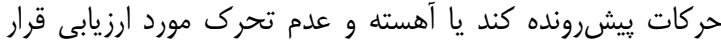

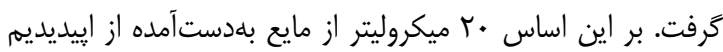

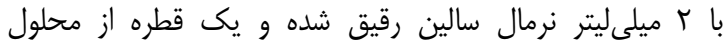

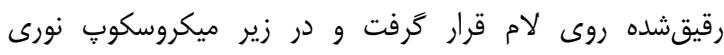
Olympus CX21FS1)

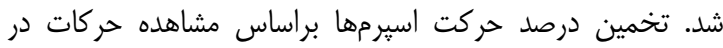

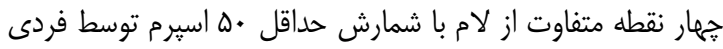

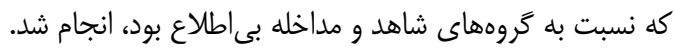

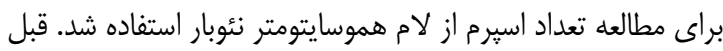

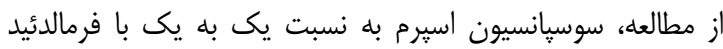

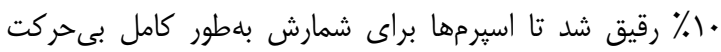

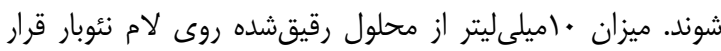

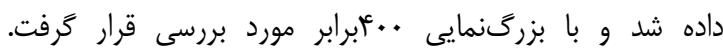
اسيرمهاى با مورفولوزى طبيعى و غيرطبيعى شمارش شدند. بس إن از

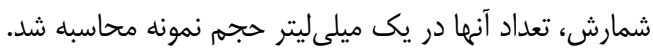




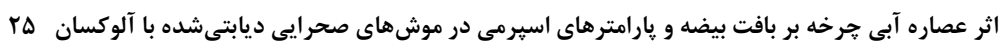

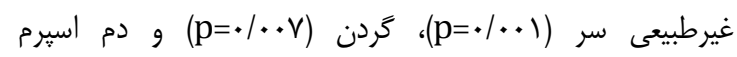

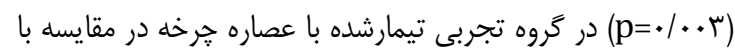

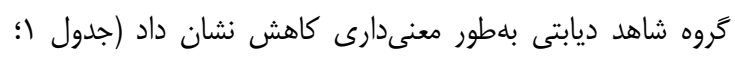

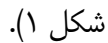

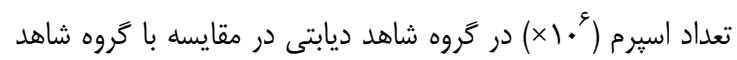

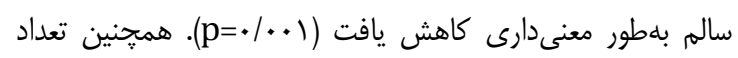

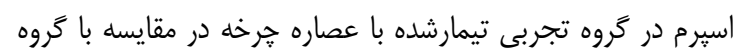

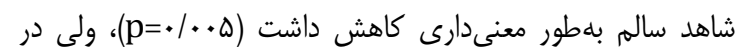

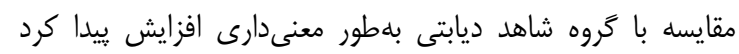

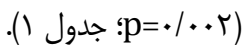

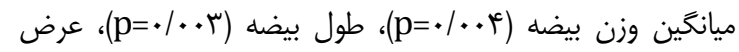

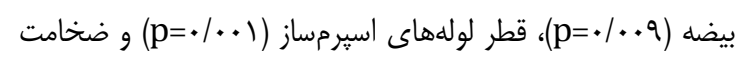

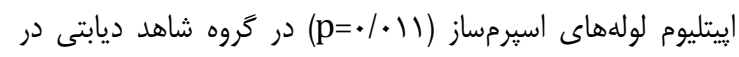

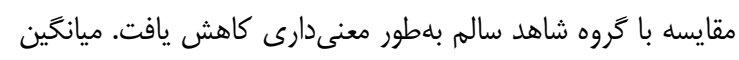

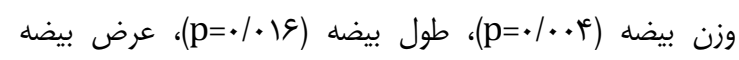

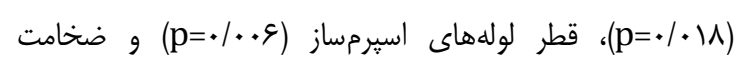

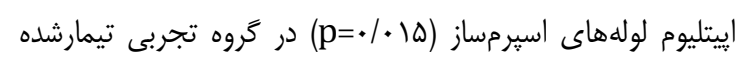

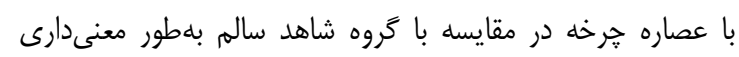

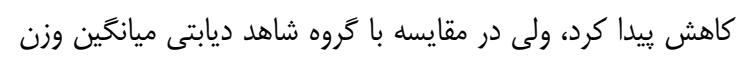

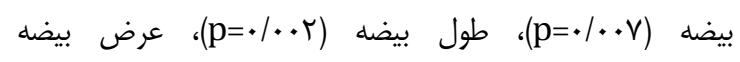

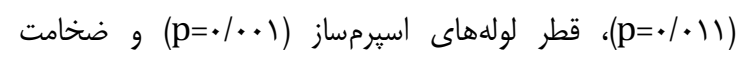

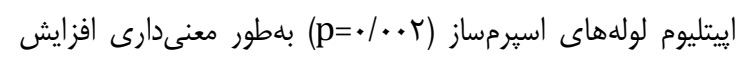

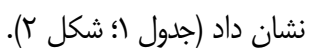

هرخه با غلظت . .ب ميلى گرم بر كيلوگرم در مقايسه با گروه شاهد

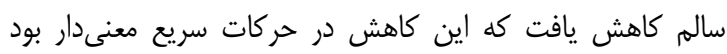

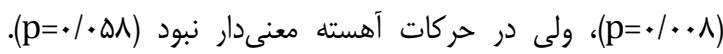

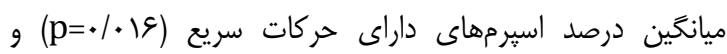

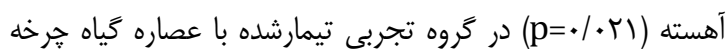

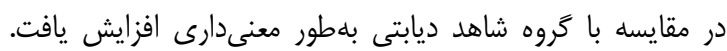

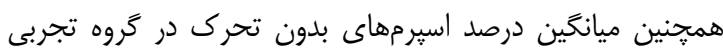

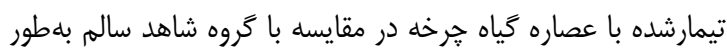

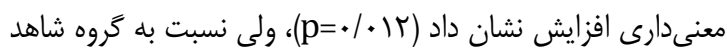

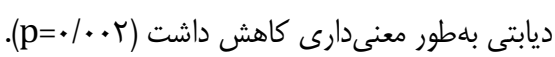

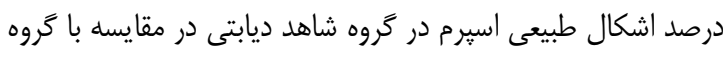

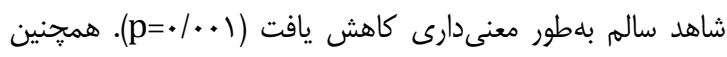
درصد اشكال طبيعى اسيرم در زروه تجربى تيمارشده با عصاره

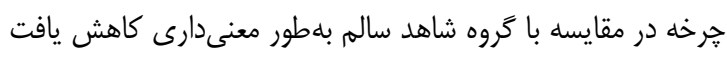

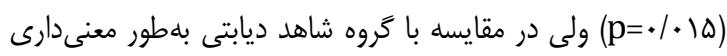

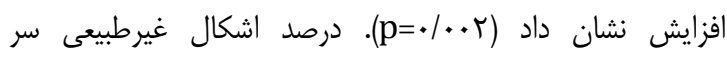

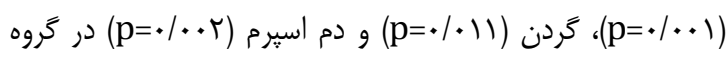

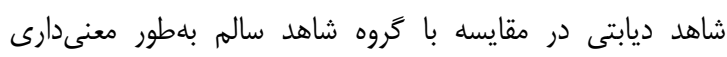

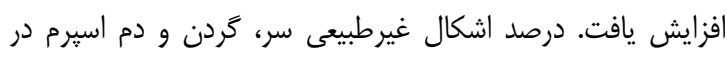

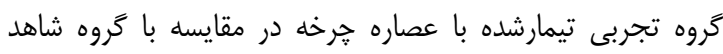

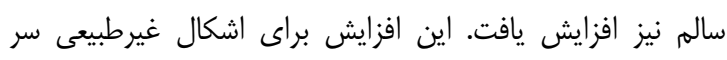

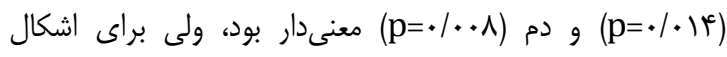
غيرطبيعى گردن معنى

جدول () مقايسه ميانگين ثارامترهاى اسيرم و بيضه موشهاى صحر ايى بهتفكيك گروه

\begin{tabular}{|c|c|c|c|}
\hline تيمار با جرخه & شاهد ديابتى & شاهد سالم & هِار امترها \\
\hline & & & ميانَين درصد حركات بِيشرونده اسير م \\
\hline $\mathrm{bqT/R} / \kappa^{c} \pm \Delta / / \mathrm{r}$ & aN $(Y \pm \pm|q|$ & $\Delta T / F \Lambda \pm T / T I$ & 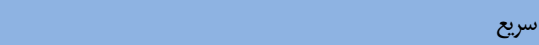 \\
\hline$c T E / \Lambda \& \pm r / \& \Lambda$ & a) $1 / \Gamma f \pm r / T \Delta$ & $r N / r E \pm T / \cdot r$ & 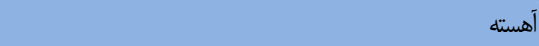 \\
\hline \multirow[t]{2}{*}{$\operatorname{bq} \mp / M \pm \Delta / M$} & $a \wedge .1 .9 \pm V / v \Delta$ & $W / q \pm E / \Lambda T$ & 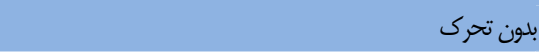 \\
\hline & & & ميانكين درصد اشكال طبيعى و غيرطبيعى اسبره \\
\hline bçN/qTEI/TV & $a \mu / \Lambda T \pm r / \Lambda \Delta$ & $9 T / T \Lambda \pm T / \Psi A$ & طبيعى \\
\hline $\mathrm{bc} / \mathrm{T} / \mathrm{TA} \pm \mathrm{V} / \mathrm{AV}$ & 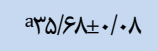 & $r / 9 q_{ \pm} .1 .9$ & سر غيرطبيعى \\
\hline$c \&|\wedge| \pm \cdot / \Lambda$ & $\operatorname{a} \mid r / \uparrow^{\wedge} \lambda \pm \cdot / \Lambda t$ & $f / T \mid \pm \cdot / I I$ & 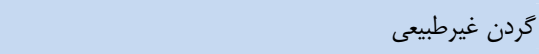 \\
\hline $\mathrm{bc}) 1 / \mathrm{Q} \pm \cdot / \mathrm{q}^{\mathrm{T}}$ & aTN/FI土./ar & $\cdot / A \vee \pm \cdot / \cdot 9$ & دم غيرطبيعى \\
\hline \multirow{3}{*}{$\mathrm{b} \vee / / \Lambda \pm \cdot|\Delta|$} & & & ميانكين تعداد اسيرم \\
\hline & $a r / M \pm \cdot / \mu l$ & $\mid r / \cdot t \pm 1 / \cdot 1$ & |. × (ميليون در هر ميلىليتر) \\
\hline & & & ميانكَين هارامترهاى بيضه \\
\hline bc) $/ \pi \pm \pm \cdot 1 \cdot \varphi$ & $\mathrm{a} \cdot / \Lambda V_{ \pm} \cdot / \cdot \mathrm{r}^{\mathrm{f}}$ & $1 / \mathcal{N} \pm \cdot / \cdot V$ & 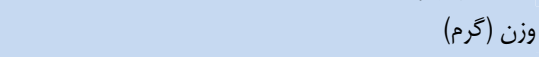 \\
\hline bcl/M" $/ \cdot / \cdot r$ & a) $/ \cdot r \pm \cdot / \cdot r$ & $1 / u_{ \pm} \cdot / \cdot \Delta$ & طول (سانتى متر) \\
\hline bc. $/ q_{ \pm} \cdot / \cdot q$ & $a \cdot \mid \& \Lambda \pm * / * \varphi^{c}$ & $|/ \pi| \pm \cdot / \cdot 9$ & عرض (سانتىمتر) \\
\hline bcTAV/ $\Delta \Phi \pm I f / T \Lambda$ & a) $\& \& / \Delta| \pm| 1 / n$ & MIN/FA \pm War & قطر لولههاى اسيرمساز (ميكرون) \\
\hline 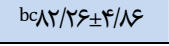 & a & $1 \cdot N / T \Delta \pm \Delta / \Delta V$ & ضخامت إيتليوم لولههاى اسيرمساز (ميكرون) \\
\hline
\end{tabular}




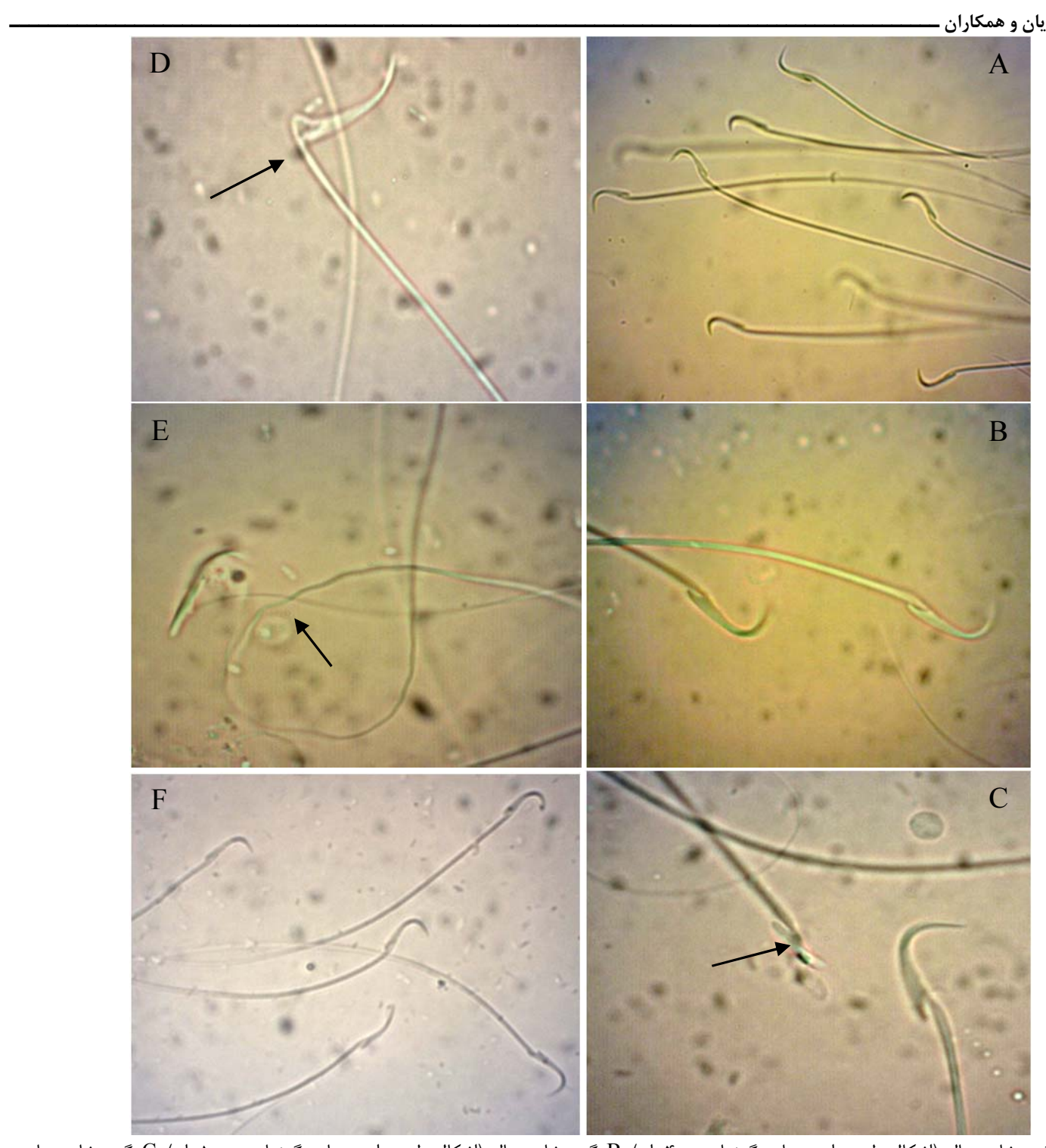

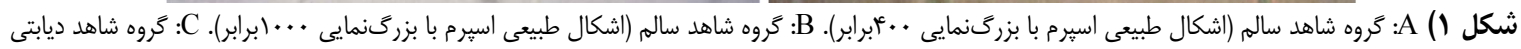

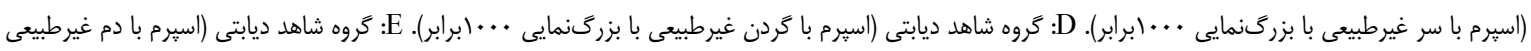

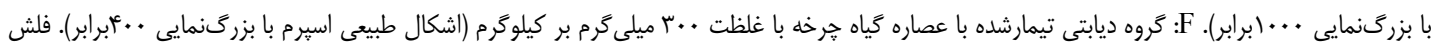
نشاندهنده ناحيه آسيبديده اسيرم است.

تماماً توسط آلو كسان ديابتى شدهاند، مىتوان بهبودى در يارامترهاى

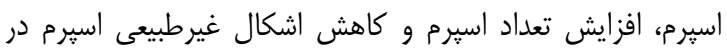

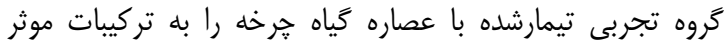

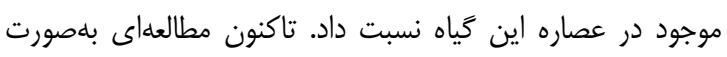

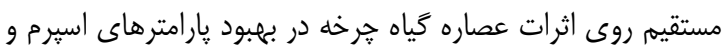

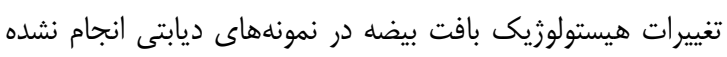

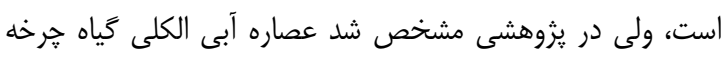

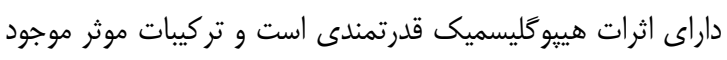

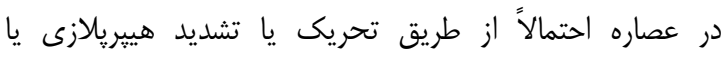

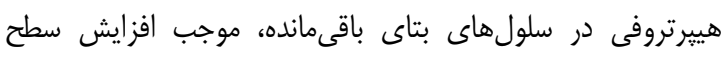
انسولين خون و كاهش سطح قند خون نمونهای داى ديابتى مى شود

\section{بحث}

در يزوهش حاضر، اثر عصاره كياه خرخه در بهبود پارامترهاى

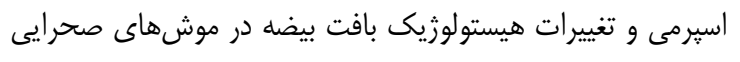

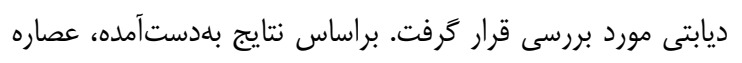

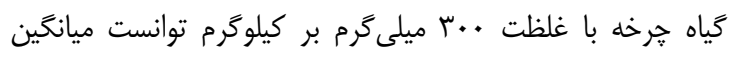

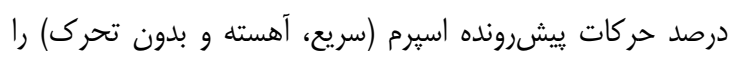

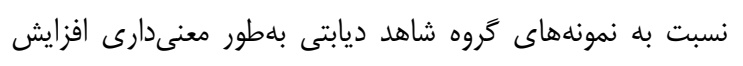

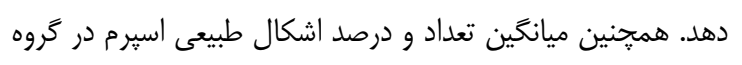

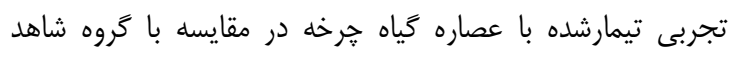

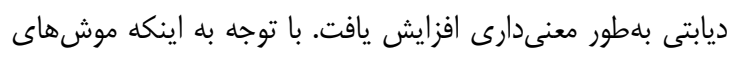

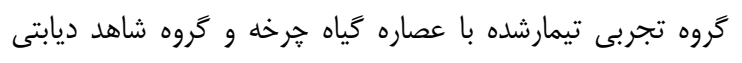




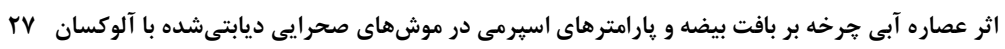

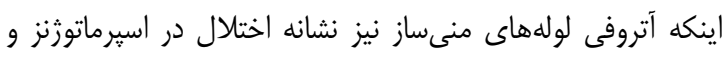

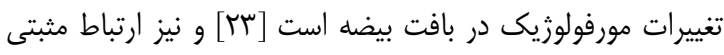

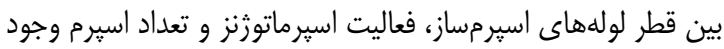

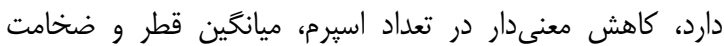

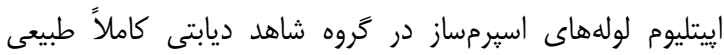

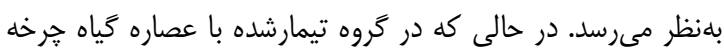

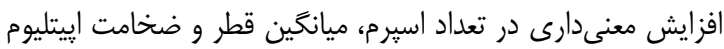
لولهاى اسيرمساز مشاهده شد.
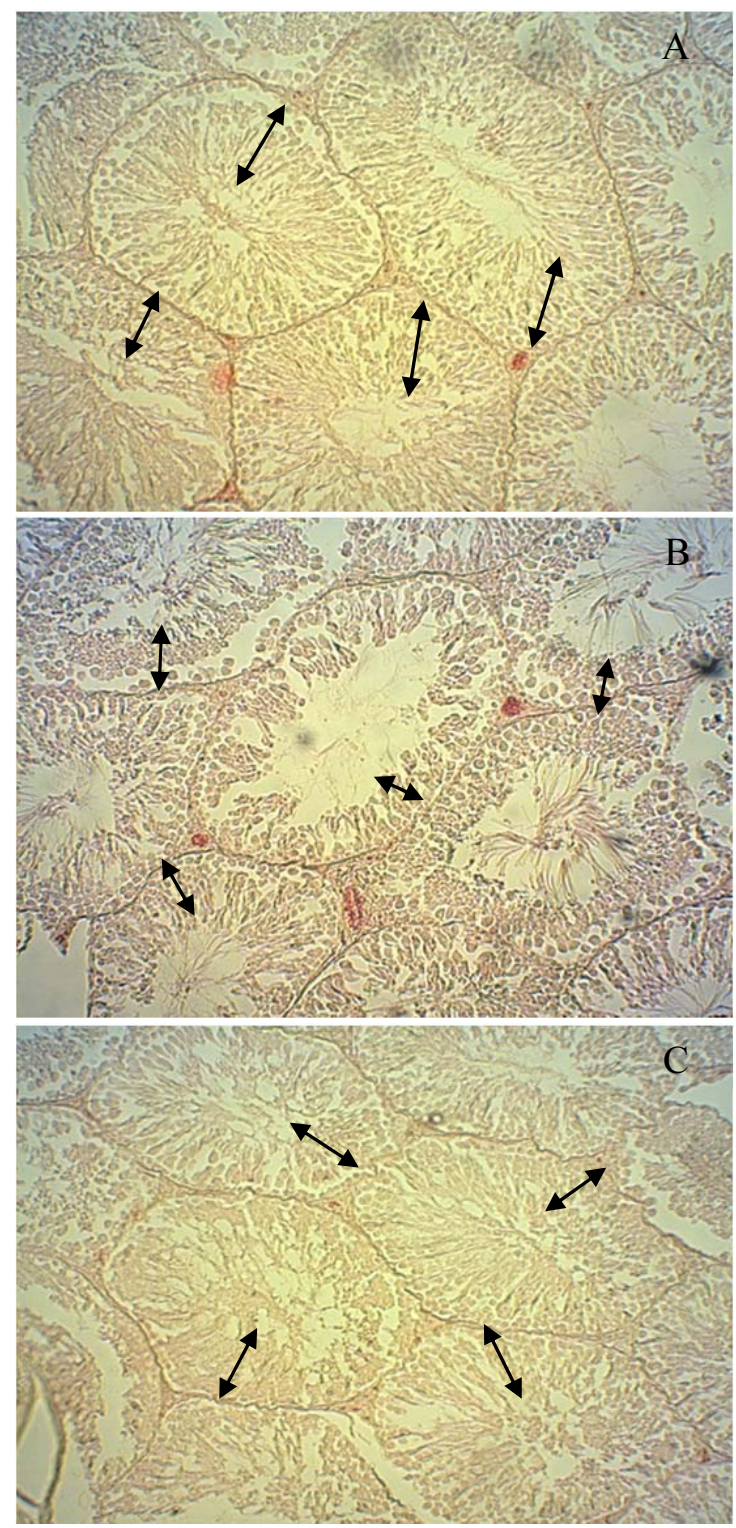

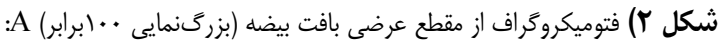

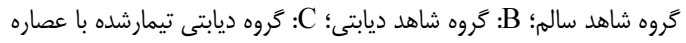

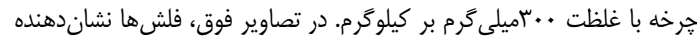

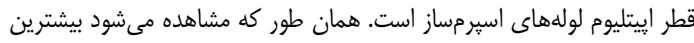

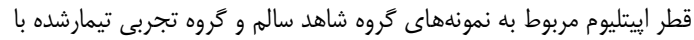
عصاره هرخه است.

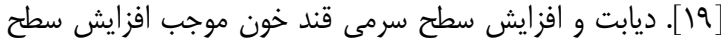
راديكالهاى آزاد و منجر به افزايش استرس اكسيداتيو سلولى مىشود [r]. از آنجايى كه استرس اكسيداتيو با تغيير در فيزيولوزى دائى طبيعى غشاهاى سلولى منجر به مركى سلولهاى زائ زايا در مراحل

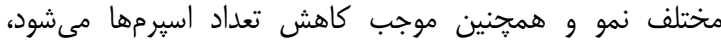

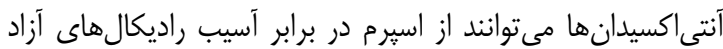

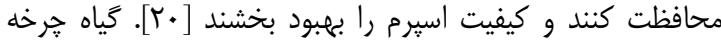

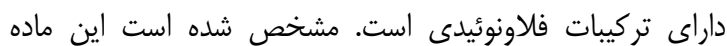

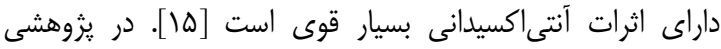

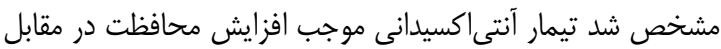

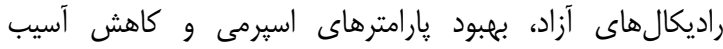

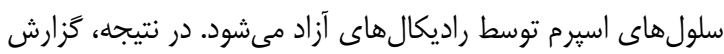

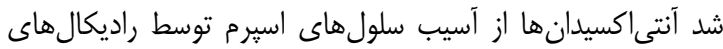

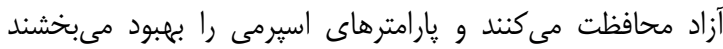

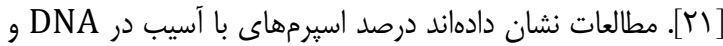
اشكال غيرطبيعى در افراد ديابتى در مقايسه با افراد سالم بلهطور

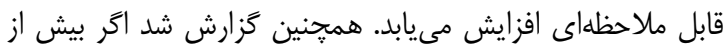

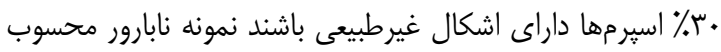

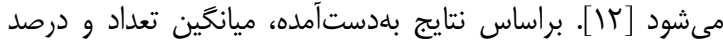
اشكال طبيعى سر، كردن و دم اسبرم در نمونههاى ديابتى تيمارشده

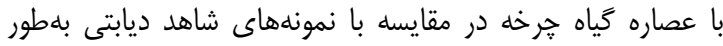

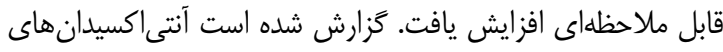
طبيعى موجود در كياهان با كاهش راديكالهاى آزاد و كاهش استرس اكسيداتيو در موشهاى ديابتى مىتوانند منجر به افزايش

اسيرماتوزنز و در نهايت موجب افزايش تعداد اسيرم شوند [برئ.

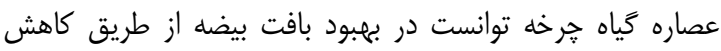

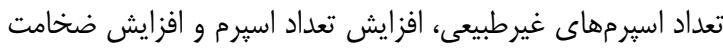

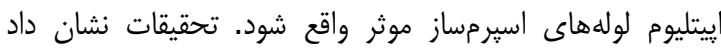
ديابت از طريق ايجاد آيويتوزيس، آتروفى لولههاى اسبرمسازئ

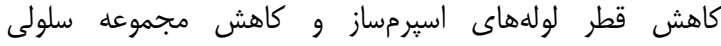

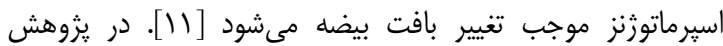
حاضر، تعداد اسيرم در كروه شاهد ديابتى در مقايسه با كَروه شاهد باهد

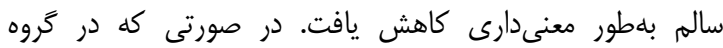

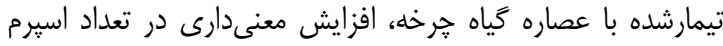
در مقايسه با كروه شاهد ديابتى مشاهده شد. تفسير اين اين نتايج مى تواند بدين صورت باشد كه تركيبات موجود در عصاره كَياه هرخه

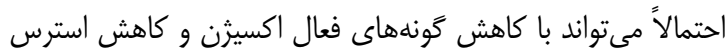
اكسيداتيو ناشى از ديابت موجب افزايش فرآيند اسبرماتورنز شود و

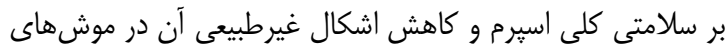

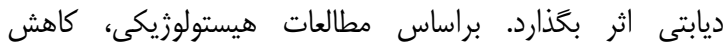
معنىدارى در تعداد اسيرم و ميانكين قطر و ضخامت دئن إيتليوم

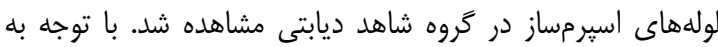


2- Rochette L, Zeller M, Cottin Y, Vergely C. Diabetes, oxidative stress and therapeutic strategies. Biochimica Biophysica Acta. 2014;1840(9):2709-29.

3- Fanaei H, Keshtgar S, Bahmanpour S, Ghannadi A, Kazeroni M. Beneficial effects of $\alpha$-tocopherol against intracellular calcium overload in human sperm. Reprod Sci. 2011;18(10):978-82.

4- Lombardo F, Sansone A, Romanelli F, Paoli D, Gandini L, Lenzi A. The role of antioxidant therapy in the treatment of male infertility: An overview. Asian J Androl. 2011;13(5):690-7.

5- Yang H, Jin X, Kei Lam CW, Yan SK. Oxidative stress and diabetes mellitus. Clin Chem Lab Med. 2011;49(11):1773-82.

6- Cui X. Reactive oxygen species: The achilles' heel of cancer cells? Antioxid Redox Signal. 2012;16(11):1212-4. 7- Saleh RA, Agarwal A. Oxidative stress and male infertility: From research bench to clinical practice. J Androl. 2002;23(6):737-52.

8- Tvrdá E, Kňažická Z, Bárdos L, Massányi P, Lukáč N. Impact of oxidative stress on male fertility - a review. Acta Vet Hung. 2011;59(4):465-84.

9- Ford WC. Regulation of sperm function by reactive oxygen species. Hum Reprod Update. 2004;10(5):38799.

10- Roessner C, Paasch U, Kratzsch J, Glander H, Grunewald S. Sperm apoptosis signalling in diabetic men. Reprod Biomed Online. 2012;25(3):292-9.

11- Kilarkaje N, Al-Hussaini H, Al-Bader MM. Diabetesinduced DNA damage and apoptosis are associated with poly (ADP ribose) polymerase 1 inhibition in the rat testis. Eur J Pharmacol. 2014;737:29-40.

12- Yun JI, Gong SP, Song YH, Lee ST. Effects of combined antioxidant supplementation on human sperm motility and morphology during sperm manipulation in vitro. Fertil Sterility. 2013;100(2):373-8.

13- Hajinejad Boshroue R, Behnam Rassouli M, Tehranipour M, Gheybi F, Hajinejad Sh, Elahi Moghadam Z. The effects of hydro-alcoholic extract of launaea acanthodes on the blood, urine albumin and bilirubin levels in male hyperglycemic wistar rat. Iranian J Endocrinol Metabolism. 2013;15(2):190-6. [Persian]

14- Piazza L, Bertini S, Milany J. Extraction and structural characterization of the polysaccharide fraction of Launaea acanthodes gum. Carbohydr Polymers. 2010;79(2):449-54.

15- Karimidokht Shahrbabaki A, Oryan Sh, Parivar K. Anticonvulsant activity of ethanolic extract and aqueous fraction of Launaea acanthodes gum in comparison with diazepam in mice. J Qazvin Univ Med Sci. 2009;13(1):1420. [Persian]

16- Sadooghi SD, Nezhad Shahrokh Abadi Kh, Zafar Balanzhad S, Baharara J. Investigating the cytotoxic effect of ethanolic extract of Ferula assa-foetida resin on HepG 2 cell line. Feyz. 2013;17(4):323-30. [Persian] 17- Kheradmand A. Improvement of sperm evaluation parameters following ghrelin treatment in cadmiuminduced testicular injury in rats. J Isfahan Med Sch. 2014;31(265):2053-62. [Persian]

18- Tajaddini Sh, Ebrahimi S, Shirinbayan P, Bakhtiyari M, Behnam B, Joghataei MT, et al. Protective effects of manganese on the testis structure and sperm parameters of formalin-treated mice. J Isfahan Med Sch. 2013;31(243):1018-32. [Persian]

19- Behnam-Rassouli M, Ghayour N, Ghayour MM, Ejtehadi MM. Investigating the effects of hydro-alcoholic extract of Launaea acanthodes on the serum levels of

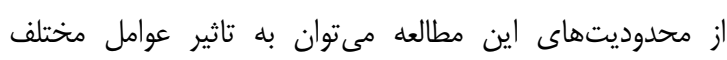

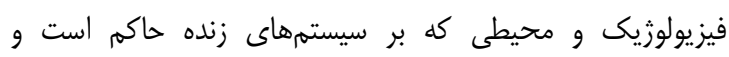

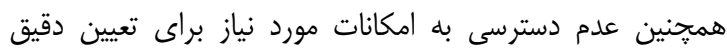

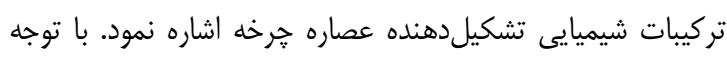

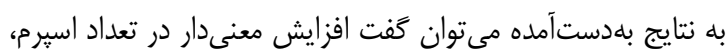

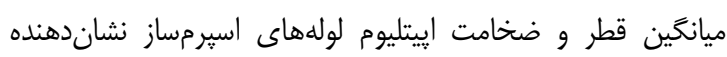

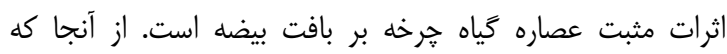

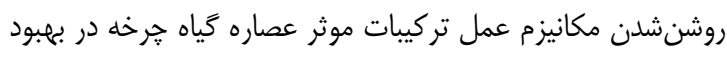

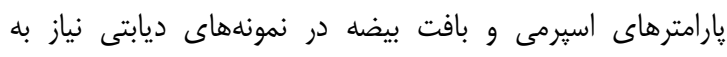

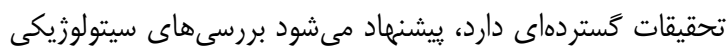

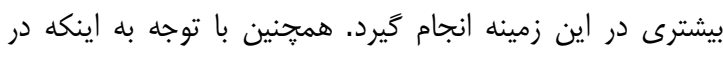

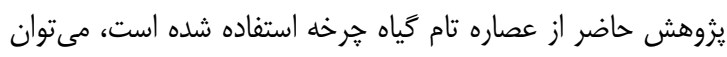

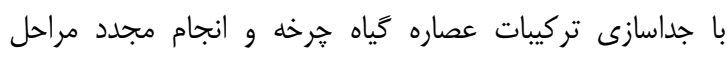

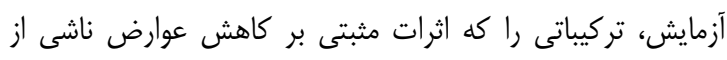

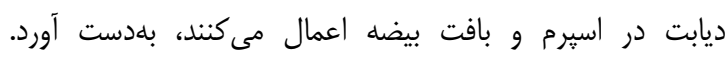

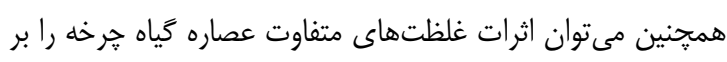
سطح سرمى قند خون و هورمونهاى انسولين و تستوسترون

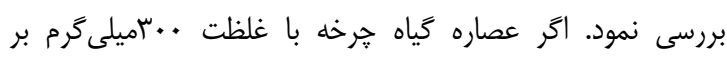
كيلوگرم موجب كاهش معنىدارى در سطح سرمى قند خون و

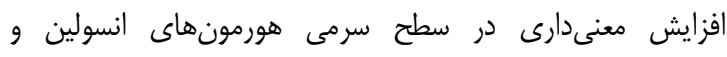
تستوسترون در مقايسه با شاهد ديابتى شود مىتواند تكميل و

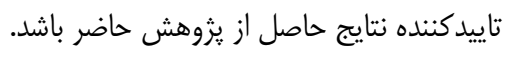

\section{نتيجه كَيرى}

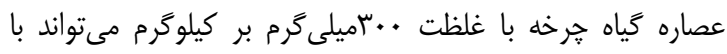
تاثير بر بافت بيضه موجب كاهش آتروفى لولههاى اسيرمساز در بر براه

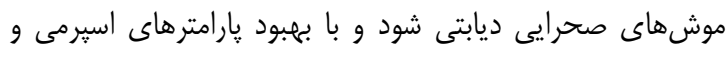

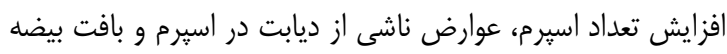

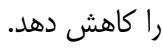

تشكر و قدردانى: بدين وسيله نويسندگان مقاله مراتب تشكر و

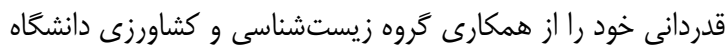
ييام نور در انجام اين يروزه تحقيقاتى ابراز مىنمايند.

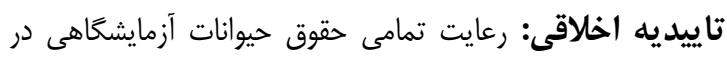

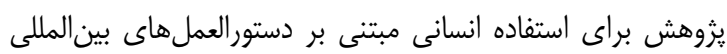

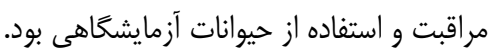
تعارض منافع: موردى از طرف نويسندكان بيان نشده است. منابع مالى: منابع مالى اين يزوهش توسط دانشعاه يِيام نور تامين شده است.

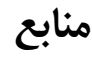

1- Hinman RM, Smith MJ, Cambier JC. B cells and type 1 diabetes ...in mice and men. Immunology Lett. 2014;16(2):128-32.

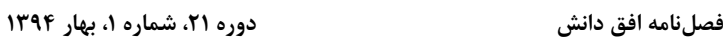




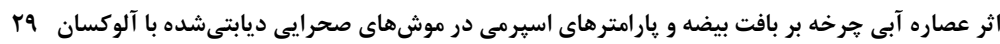

Biochemistry. 2011;44(4):319-24.

22- Zhong RZh, Zhou DW. Oxidative stress and role of natural plant derived antioxidants in animal reproduction. J Integr Agric. 2013;12(10):1826-38.

23- Stefanović A, Kotur-Stevuljević J, Spasić S, Bogavac-

Stanojević N, Bujisić N. The influence of obesity on the oxidative stress status and the concentration of leptin in type 2 diabetes mellitus patients. Diabetes Res Clin Pract. 2008;79(1):156-63. glucose, insulin, lipids and lipoproteins in stereptozotocin induced type I diabetic rats. Arak Med Univ J. 2012;14(6):48-56. [Persian]

20 - Yousef MI. Protective role of ascorbic acid to enhance reproductive performance of male rabbits treated with stannous chloride. Toxicol. 2005;207(1):81-9.

21- Shiva M, Gautam AK, Verma Y, Shivgotra V, Doshi H, Kumar S. Association between sperm quality, oxidative stress, and seminal antioxidant activity. Clin 